\title{
CCSER1 Gene
}

National Cancer Institute

\section{Source}

National Cancer Institute. CCSER1 Gene. NCI Thesaurus. Code C112489.

This gene may be involved in mitosis. 